\title{
Physiological and Biochemical Responses of Indian Mustard (Brassica juncea L.) Genotypes to Different Sowing Dates
}

\author{
Ajeev Kumar ${ }^{1}$, Mahesh Kumar ${ }^{1}$, Parveen Gill ${ }^{2}$, Dharamvir ${ }^{1}$ and Neeraj Kumar ${ }^{1}$ \\ ${ }^{1}$ Department of Botany \& Plant Physiology, ${ }^{2}$ Department of Zoology, CCS Haryana \\ Agricultural University, Hisar - 125004, India \\ *Corresponding author
}

\section{A B S T R A C T}

The experiment was conducted with 6 genotypes of Indian mustard (Brassica juncea L.) viz RH-0116, RH-725, RH-923, RH-1019, RH-1077, RH-1301 for three dates of sowing i.e 23

\section{Keywords}

Sowing dates,

Physiological traits, Proline, Genotypes

Article Info

Accepted:

20 November 2018

Available Online:

10 December 2018
September, 16 October and 21 November in the field in randomized block design during rabi season of 2015-16 at Oil Seed Section, Chaudhary Charan Singh Haryana Agricultural University, Hisar with an objective was to study the changes for the physiological traits like water potential, osmotic potential, relative water content, relative stress injury, canopy temperature depression and chlorophyll a fluorescence and biochemical traits like proline and glycine betaine content. The values of all the physiological traits were maximum on 16 October sowing and minimum on 21 November sowing except relative stress injury which was maximum on 21 November and minimum on 16 October and the canopy temperature depression was maximum on 23 September sowing and minimum on 16 October sowing. The accumulation of proline and glycine betaine content was maximum on 21 November sowing and minimum on 16 October. Results showed that among sowing dates, 16 October sowing was the best for Indian mustard and genotypes RH-0116 performed better in terms of all physiological as well as biochemical traits.

\section{Introduction}

Oilseeds crops are the second most important determinant of agricultural economy, next only to cereals. Today, the demand for vegetable oils is out pacing the supply with more than half of its annual requirements being met mainly through imports. India is the 5th largest vegetable oil economy in the world next to USA, China, Brazil and Argentina accounting for $7.4 \%$ world oilseed output, 6.1 $\%$ of oil meal production, $3.9 \%$ world oil meal export 5.8\% vegetable oil production, $11.2 \%$ of world oil import and $9.3 \%$ of the world edible oil consumption (DRMR, 2013, Vision 2020). Rapeseed-mustard (Brassica spp.) is one of the most important oilseed crops of the world where India is ranking third in area and production in the world (DRMR, 2015). Its seed contains 37 to 49 percent edible oil (Singh et al., 2009). Indian mustard (Brassica juncea $\mathrm{L}$. Czern) belongs to family Cruciferae, genus Brassica and species juncea popularly known as rai. Mustard is cultivated mostly 
under temperate climate. It is also cultivated in certain tropical and subtropical region as a cold weather crop. In India, rapeseed-mustard occupy 5.99 million ha area with production and productivity of 6.31 million tones and $1053 \mathrm{~kg} / \mathrm{ha}$ respectively (India stat 2014-15). Indian mustard (Brassica juncea L.) is an important rabi crop of Haryana. In Haryana, rapeseed and mustard is one of the major growing crop occupying 0.56 million ha of area, with production and productivity of 0.699 million tones and $1248 \mathrm{~kg} / \mathrm{ha}$ respectively (India stat 2014-15). Indian mustard is sown late due to delay in harvesting of rainy season crops like cluster bean, cotton and rice (Kumar et al., 2013). Under late sown condition, productivity declines primarily due to the shortening of vegetative and reproductive phase. Late sown Indian mustard is exposed to high temperature coupled with high evaporative demand of the atmosphere, during the reproductive phase which consequently results in forced maturity, increased senescence and low productivity (Porter, 2005). The rise in temperature, even by a single degree beyond the threshold level is considered as heat stress in the plants (Hasanuzzaman et al., 2013; Wahid et al., 2007). The global mean surface air temperature increased by $0.5^{\circ} \mathrm{C}$ in the twentieth century and is expected to increase a further $1.5-4.5^{\circ} \mathrm{C}$ by the late twenty-first century (IPCC, 2012). Climate change has increased the intensity of heat stress and heat stress due to increased temperature is an agricultural problem in many areas in the world as well as in India (Beck et al., 2007).

Transitory or constantly high temperatures cause an array of morphological, physiological and biochemical changes in plants (Serraj et al., 1999, Moradshahi et al., 2004). The high temperature adversely affected the photosynthesis, respiration, water relations and membrane stability, enhanced expression of a variety of heat shock proteins and production of reactive oxygen species (ROS) constitute major plant responses to heat stress (Wahid et al., 2007; Camejo et al., 2006).

Extreme temperature leads to accumulation of certain organic compounds (osmolytes) like sugars, polyols, proline and glycine betaine (Kavikishor et al., 2005; Sairam and Tyagi, 2004). These solutes have several protective roles in heat-stressed cells (Jain et al., 2007; Rasheed et al., 2010).

There is a specific time for the sowing of particular variety of a crop on specific area (Robertson et al., 2004; Uzun et al., 2009). Ideal sowing dates for one or more variety allows for availability of a set of environmental factor that favour a desirable greening, establishment and survival of plantlet which as a result the plant encounters the favorable environmental conditions and avoid unfavorable ones during each stage of its growth (Khajepour, 2001).

\section{Materials and Methods}

The experiment was conducted at research area of Oil Seed Section, in the Department of Genetics and Plant Breeding of Chaudhary Charan Singh Haryana Agricultural University, Hisar during Rabi 201516.Geographically the experimental field was located at $29{ }^{\circ} .10^{!} \mathrm{N}$ latitude and $75^{\circ} .46$ longitude at an elevation of 215.2 meters above the mean sea level. The average rainfall varies from $300-500 \mathrm{~mm}$ and about $80-90$ per cent of the total rains are received from SouthWest monsoon during the month of July to September. The minimum temperature in this area reaches upto $0.5{ }^{\circ} \mathrm{C}$ in December and January and the maximum temperature in the area reaches upto $48{ }^{\circ} \mathrm{C}$ during May or June. The experimental soil having $57.93 \%$ sand, $26.03 \%$ silt and $16.04 \%$ clay particles, $\mathrm{EC}=$ $0.20 \mathrm{dSm}^{-1}$ at $25^{\circ} \mathrm{C}, \mathrm{pH}=8.0$, Organic carbon $=0.30 \%$, Nitrogen $=143.4 \mathrm{~kg} \mathrm{ha}{ }^{-1}$, 
Phosphorus $=17 \mathrm{~kg} \mathrm{ha}^{-1}$, Potassium $=172 \mathrm{~kg}$ $\mathrm{ha}^{-1}$. The crop was planted in rows spaced $45 \mathrm{~cm}$ with $30 \mathrm{~cm}$ plant to plant distance. The genotypes of mustard were RH-0116, RH-725, RH-923, RH-1019, RH-1077, RH-1301. The experimental treatments were 3 sowing dates viz. $D 1=23^{\text {rd }}$ September, D2 $=16^{\text {th }}$ October, D3 $=21^{\text {st }}$ November. The experimental design was Randomized Complete Block Design (RCBD) with three replications having plot size $1.5 \mathrm{~m} \times 5.0 \mathrm{~m}$. Data were collected on Water potential (W.P), Osmotic potential (O.P), Relative water content (RWC), Relative stress injury (RSI), Canopy temperature depression(CTD), Chlorophyll a fluorescence (fv/fm), Proline and Glycine betaine. Water potential of leaf was measured with the help of pressure chamber. The osmotic potential was measured by Vapor Pressure Osmometer. The relative water content was calculated by formula given by Weatherley (1950). Photochemical efficiency / quantum yield was determined in intact plants in the field with an OS-30P Chlorophyll Flurometer. Canopy temperature depression measurements were made by using a handy Infrared Thermometer. Membrane injury index was measured by method given by Sallivan and Ross, (1979). Proline content was estimated by using the method of Bates et al., (1973). Glycine betaine was measured according to Grieve and Grattan (1983) and all the collected data were statistically analyzed by the OPSTAT software at the Computer Centre, Department of Statistics, CCS HAU, Hisar.

\section{Results and Discussion}

The data presented in Table 1 indicated that among three dates of sowings, lowest leaf water potential, osmotic potential and RWC was recorded in crop sown on November 21 and highest was recorded in October 16 sowing. This might be due to the reason that the low temperature at 21 November sowing condition might have inhibited the water absorption from the soil by the roots due to slow physiological processes that might have resulted into poor root growth while on 16 October sowing, might have favorable temperature for root growth that resulted into higher water potential, osmotic potential and RWC. Similar results due to different sowing dates has also been reported earlier in the literature (Maharaj et al., 2009; Sinaki et al., 2007; Gan et al., 2004; Sudhir et al., 2013; Ram et al., 2015 in Brassica juncea).

Among genotypes, highest leaf water potential, osmotic potential and RWC was recorded in genotype $\mathrm{RH}-725$ and minimum was in RH-1019. This is because of variation in different genotypes in their genetic makeup which is well reported in the literature (Sudhir et al., (2013); Ram et $a l$. , (2014). The lowest relative stress injury (RSI) in leaf was recorded in crop sown on October 16 and highest was recorded in November 21 sowing. This might be due to the reason that the decreased water potential, osmotic potential and RWC in leaf due to very low temperature prevailing on 21 November sowing condition that might have resulted into the severe injury to the leaf while on 16 October sowing condition the sufficient water potential, osmotic potential and RWC due to optimum environmental condition might have prevented the injury to the leaf. Similar results due to different sowing dates has also been reported in the literature (Ram et al., (2014); Sudhir et al., (2013); Wilson et al., (2012); Du et al., (2009) in mustard crop. In all the genotypes lowest relative stress injury was recorded in genotype RH-0116 and maximum was recorded in RH-1019. This is because of variation in different genotypes in their genetic makeup which is well reported in literature (Ram et al., 2014; Sudhir et al., 2013). 
The maximum chlorophyll a fluorescence was recorded in crop sown on October 16 and minimum was recorded in November 21 sowing. This might be due to the reason that the foggy and cloudy weather conditions prevailing on 21 November sowing that might have resulted into the limited photosynthesis while the bright sunshine hours and clear weather conditions on 16 October sowing that might have resulted into the sufficient amount of photosynthesis which increases the chlorophyll a fluorescence. Similar results due to different sowing dates have also been reported earlier in the literature (Singh et al., (2014); Ristic et al., (2008) in Brassica juncea; Basu et al., (2011) in chickpea). In all the genotypes highest chlorophyll a fluorescence was recorded in genotype RH-0116 and lowest was recorded in $\mathrm{RH}-1019$. This is because of variation in different genotypes in their genetic makeup which is well reported in the literature (Singh et al., (2014); Ram et al., (2012) in Brassica juncea. The maximum canopy temperature depression was observed in the crop sown on September 23 and minimum was observed in October 16 sowing. This might be due to the reason that high temperature prevailing on 23 September sowing condition that might have resulted into more canopy temperature depression while on 16 October sowing the prevailing temperature was optimum for Brassica that might have resulted into less canopy temperature depression. Similar results due to different sowing dates have also been reported earlier in the literature (Basu et al., (2014); Rosyara et al., (2010) in wheat; Kumar et al., (2012) in chickpea). Among genotypes, lowest canopy temperature depression was recorded in genotype $\mathrm{RH}-$ 0116 and highest canopy temperature depression was recorded in genotype $\mathrm{RH}-$ 1019. This is because of variation in different genotypes in their genetic makeup which is well reported in the literature (Basu et al., (2014) in wheat; Kumar et al., (2012) in chickpea).

Table.1 Effect of sowing dates on physiological and biochemical traits of Indian mustard

\begin{tabular}{|l|l|l|l|l|l|l|l|l|}
\hline Treatments & $\begin{array}{l}\text { W.P } \\
(-\mathrm{Mpa})\end{array}$ & $\begin{array}{l}\text { O.P } \\
(-\mathrm{Mpa})\end{array}$ & $\begin{array}{l}\text { R.W.C } \\
(\%)\end{array}$ & $\begin{array}{l}\text { R.S.I } \\
(\%)\end{array}$ & $\begin{array}{l}\text { C.T.D } \\
\left({ }^{0} \mathrm{C}\right)\end{array}$ & FV/FM & $\begin{array}{l}\text { Proline } \\
\left(\mathrm{mg} \mathrm{g}^{-1} \mathrm{DW}\right)\end{array}$ & $\begin{array}{l}\text { Glycine } \\
\text { Betaine } \\
\left(\mathrm{mg} \mathrm{g}^{-1} \mathrm{DW}\right)\end{array}$ \\
\hline Sowing dates & & & & & & & & \\
\hline 23 September & 0.46 & 0.47 & 74.1 & 6.38 & -5.43 & 0.663 & 0.397 & 0.055 \\
\hline $\mathbf{1 6}$ October & 0.33 & 0.32 & 82.3 & 4.55 & -3.41 & 0.694 & 0.266 & 0.039 \\
\hline 21 November & 0.62 & 0.62 & 67.7 & 9.98 & -4.42 & 0.646 & 0.541 & 0.079 \\
\hline CD at 5 \% & 0.01 & 0.01 & 0.5 & 0.11 & 0.07 & 0.010 & 0.008 & 0.003 \\
\hline Genotypes & & & & & & & & \\
\hline RH-0116 & 0.38 & 0.40 & 77.1 & 6.03 & -4.20 & 0.681 & 0.432 & 0.067 \\
\hline RH-725 & 0.41 & 0.43 & 77.2 & 6.30 & -4.23 & 0.677 & 0.429 & 0.066 \\
\hline RH-923 & 0.47 & 0.45 & 73.5 & 7.35 & -4.50 & 0.663 & 0.391 & 0.053 \\
\hline RH-1019 & 0.55 & 0.56 & 72.9 & 7.64 & -4.63 & 0.657 & 0.380 & 0.051 \\
\hline RH-1077 & 0.54 & 0.52 & 73.9 & 7.58 & -4.53 & 0.665 & 0.386 & 0.054 \\
\hline RH-1301 & 0.47 & 0.47 & 73.8 & 6.93 & -4.45 & 0.664 & 0.388 & 0.055 \\
\hline CD at 5 \% & 0.01 & 0.01 & 0.8 & 0.16 & 0.10 & 0.014 & 0.011 & 0.005 \\
\hline
\end{tabular}


The maximum proline and glycine betaine content in leaf was recorded in crop sown on November 21 and minimum was observed in October 16 sowing. This might be due to the reason that the low temperature prevailed on 21 November that might have resulted into the more accumulation of proline and glycine betaine content due to cold stress while on 16 October sowing the prevailing temperature was optimum as the 16 October was the normal sown condition for mustard crop that might have resulted into less accumulation of proline and glycine betaine content. Similar results have also been reported earlier in the literature (Kaushal et al., (2011); Kumar et al., (2012) in chickpea; Takeda et al., (2000); Hayat et al., (2009) in mustard; Ahmed and Hasan (2011) in wheat; Moharramnejad et al., (2015) in maize. Among genotypes maximum proline and glycine betaine content in leaf was recorded in genotype $\mathrm{RH}-0116$ and minimum was recorded in $\mathrm{RH}-1019$. This is because of variation in different genotypes in their genetic makeup which is well reported in the literature (Kumar et al., (2012) in chickpea; Moharramnejad et al., (2015) in maize).

From the results it may be concluded that under agroclimatic condition of Hisar, maximum physiological and biochemical traits of Brassica juncea cultivars can be obtained if these cultivars were sown on October 16 . The genotype $\mathrm{RH}-0116$ proved to be best among all studied genotypes in terms of all the above traits.

\section{References}

Ahmed, J. U., and Hasan, M. A. (2011) Evaluation of seedling proline content of wheat genotypes in relation to heat tolerance. Bangladesh Journal of Botany 40:17-22.
Basu, P.S., Ali, M. and Chaturvedi, S.K. (2011) Terminal heat stress adversely affects chickpea productivity in northern India - strategies to improve thermotolerance in the crop under climate change. Workshop Proceedings: Impact of Climate Change on Agriculture 189.

Basu, S., Parya, M., Dutta, S.K., Maji, S., Jena, S., Nath, R. and Chakraborty, P.K. (2014) Effect of canopy temperature and stress degree day index on dry matter accumulation and grain yield of wheat (Triticum aestivum 1.) sown at different dates in the indo-gangetic plains of eastern India. Indian Journal of Agriculture, 48(3): 167-176.

Bates, L., Waldren, R. P., and Teare, J. D. (1973) Rapid determination of free proline for water stress studies. Plant Soil. 39: 205-207.

Beck, E. H., Fettig, S., Knake, C., Hartig, K., and Bhattarai, T. (2007) Specific and unspecific responses of plants to cold and drought stress. Journal of Biosciences 32:501-510.

Camejo, D., Jim'enez, A., Alarc'on, J.J., Torres, W., G'omez, J.M., Sevilla, F., (2006) Changes in photosynthetic parameters and antioxidant activities following heat-shock treatment in tomato plants. Functional Plant Biology, 33: 177-187.

DRMR. 2015. Vision 2050. Directorate of Rapeseed-Mustard Research, Bharatpur, Rajasthan.:2. http://www.icar.org.in/ vision\%202050\%20DRMR\%20Rajasth an.pdf

DRMR.2013. Directorate of RapeseedMustard Research, Bharatpur, Rajasthan. www.drmr.res.in/about_rm. html.

Du, H., Z, Wang and B, Haung. (2009) Differential response of warm season and cool season turfgrass species to heat stress associated with antioxidant 
enzyme activity. Journal of American Society in Horticulture Science. 134: 417-422.

Gan, Y., Angadi, S. V., Cutforth, H. W., Potts, D., Angadi, V. V., McDonald, C. L. (2004) Rapeseed and mustard response to short period of high temperature and water stress at different developmental stages. Canadian Journal of Plant Science. 84:697-704.

Grieve, C. M., and Grattan, S. R. (1983) Rapid assay for determination of watersoluble quaternary amino compounds. Plant Soil.70:303-307.

Hasanuzzaman, M., Nahar, K., Alam, M. M., Roychowdhury, R. and Fujita, M. (2013) Physiological, biochemical, and molecular mechanisms of heat stress tolerance in plants. International Journal of Molecular Sciences 14:96439684.

Hayat, S., Masood, A., Yusuf, M., Fariduddin, Q. and Ahmad, A. (2009) Growth of Indian mustard (Brassica juncea L.) in response to salicylic acid under high-temperature stress Brazilian Journal of Plant Physiology 21:187195.

India Statistics 2014-15. (Indiastat.com).

IPCC. (2012) Managing the risks of extreme events and disasters to advance climate change adaptation. In C. B. Field, V. Barros, T. F. Stocker, D. Qin, D. J. Dokken, K. L. Ebi, M. D. Mastrandrea, K. J. Mach, G. K. Plattner, S. K. Allen, M. Tignor and P. M. Midgley (Eds.), A special report of working groups $I$ and II of the intergovernmental panel on climate change ( $\mathrm{p}$. 582). Cambridge: Cambridge University Press.

Jain, M., Prasad, P. V. V., Boote, K. J., Hartwell, A. L., and Chourey, P. S. (2007) Effects of season-long high temperature growth conditions on sugar-to-starch metabolism in developing microspores of grain
sorghum(Sorghum bicolor L. Moench). Planta. 227: 67-79.

Kaushal, N., Gupta, K., Bhandari, K.., Kumar, S., and Thakur, P. (2011) Proline induces heat tolerance in chickpea (Cicer arietinum L.) plants by protecting vital enzymes of carbon and antioxidative metabolism. Physiology \& Molecular Biology of Plants. 17: 203213.

Kavi Kishore, P.B., Sangam, S., Amrutha, R.N., Laxmi, P.S., Naidu, K.R., Rao, K.R.S.S., Rao, S., Reddy, K.J., Theriappan, P., Sreenivasulu, N., (2005) Regulation of proline biosynthesis, degradation, uptake and transport in higher plants, its implications in plant growth and abiotic stress tolerance. Current Science. 88: 424-438.

Khajepour, M.R., (2001) Principals and Essentials of crop Production. JihadUniversity Press. Isfahan University, pp: 201.

Kumar, S., Sairam, R. K and Prabhu, K. V. (2013) Physiological traits for high temperature stress tolerance in Brassica juncea. Indian Journal of Plant Physiology. 18: 89-93.

Maharaj Singh., Gupta, R. K and Chauhan, J. S. (2009) Biochemical Basis of high temperature tolerance during germination in Indian mustard (Brassica juncea L.). Indian Journal of Plant Physiology, 4: 372-377.

Moharramnejad, S., Sofalian, O.,Valizadeh, M.,Asgari, A., Shiri, M. (2015) Proline, glycine betaine, total phenolics and pigment contents in response to osmotic stress in maize seedlings. Journal of Biological Science \& Biotechnology, 4(3): 313-319.

Moradshahi, A., Eskandari, B.S. and Kholdebarin, B. (2004) Some physiological responses of canola (Brassica napus L.). Iranian Journal of Science and Technology 28:43-50. 
Porter, J. R. (2005) Rising temperatures are likely to reduce crop yields. Nature, 436: 174.

Ram, B., Meena, H.S., Singh, V.V., Singh, B.K., Nanjundan, J., Kumar, A., Singh, S.P., Bhogal N.S. and Singh, D. (2014) High temperature stress tolerance in Indian mustard (Brassica juncea)germplasm as evaluated by membrane stability index and excisedleafwater loss techniques. Journal of Oilseed Brassica, 5 (2): 149-157.

Ram, B., Singh, B.K., Singh, M., Singh, V.V., Chauhan, J.S. (2012) Physiological and molecular characterization of Indian mustard (Brassica juncea L.) genotypes for high temperature tolerance. Crop Improvement (Special issue). ICSA: 56.

Ram, B., singh, V.V., Singh, B.K., Priyamedha, kumar A. and Singh, D.(2015) Comparative tolerance and sensitive response of Indian mustard (brassica juncea 1. czern and coss) genotypes to high temperature stress. SABRAO Journal of Breeding and Genetics, 47 (3): 315-325.

Rasheed, R., Wahid, A., Ashraf, M., and Basra, S. M. A. (2010) Role of proline and glycine betaine in improving chilling stress tolerance in sugarcane buds at sprouting. International Journal of Agricultural and Biology. 12: 1-8.

Ristic, Z., Bukovnik, U., Prasad, P. V, West, M. (2008) A model for prediction of heat stability of photosynthetic membranes. Crop Science. 48: 15131522 .

Robertson, M.J., Holland, J.F. and Bambach, R. (2004) Response of canola and Mustard to sowing date in the grain belt of north-eastern Ausrralia. Australian Journal of Experimental Agriculture, 44: 43-52.

Rosyara, U. R., Subedi, S., Duveiller, E. and Sharma, R. C. (2010) The effect of spot bloch and heat stress on variation of canopy temperature depression, chlorophyll fluorescence and chlorophyll content of hexaploid wheat genotypes. Euphytica. 174: 377-390.

Sairam, R.K. and A. Tyagi (2004) Physiological and molecular biology of salinity stress tolerance in plants. Current Science. 86: 407-421.

Serraj, R., Sinclair, T.R. and Purcell, L.C. (1999) Symbiotic $\mathrm{N}_{2}$ fixation response to drought. Journal of Experimental Botany50: 143-155.

Sinaki, J. M., E., Majidi Heravan, A. H., Shirani Rad, G., Noormohamadi and G. Zarei. (2007) The effects of water deficit during growth stages of canola (B. napus L.), American-Eurasian. Journal of Agriculture Environmental Science. 2(4):417-422.

Singh, C., Singh, P. and Singh, R. (2009) Modern techniques of raising field crops. 2nd edition. Oxford and IBH publishing company private limited, New Delhi: 337.

Singh, M., S.S. Rathore and P. Raja. (2014)Physiological and Stress Studies of Different Rapeseed- Mustard Genotypes Under Terminal Heat Stress. International Journal of Genetic Engineering and Biotechnology. 5(2): 133-142.

Sudhir, K., Sairam, R. K., Prabhu, K. V. (2013) Physiological traits for high temperature stress tolerance in Brassica juncea. Indian Journal of Plant Physiology18: 89-93.

Sullivan, C. Y., and Ross, W. M. (1979) Selecting for drought and heat resistance in grain sorghum. Stress physiology in crop plants (pp. 263281).

Takeda, H., Cenpukelee, U., Chauhan, Y. S., Srinivasan, A., Hossain, M. M., Rashad, M. H., Hayashi, T. (1999) Studies in heat tolerance of Brassica vegetables 
and legumes at the International Collaboration Research Station. Proceedings of Workshop on Heat Tolerance of Crop.

Uzun, B., U. Zengin, S. Furat and O. Akdesir (2009) Sowing date effects on growth, flowering, seed yield and oil content of canola cultivars. Asian Journal of Chemistry 21: 1957-1965.

Wahid, A., and Close, T. J. (2007) Expression of dehydrins under heat stress and their relationship with water relations of sugarcane leaves. Biologia Plantarum. 51: 104-109.

Weatherley, P. E. (1950) Studies in the water relations of the cotton plant. I. The field measurement of water deficits in leaves. New Phytologist. 49: 81-97.

Wilson, Robin A., M.K. Sangha., S.S. Banga., A. K. Atwal and Shilpa Gupta. (2012) Heat stress tolerance in relation to oxidative stress and antioxidants in Brassica juncea. Journal of Environmental Biology, 35: 383-387.

\section{How to cite this article:}

Ajeev Kumar, Mahesh Kumar, Parveen Gill, Dharamvir, and Neeraj Kumar. 2018. Physiological and Biochemical Responses of Indian Mustard (Brassica juncea L.) Genotypes to Different Sowing Dates. Int.J.Curr.Microbiol.App.Sci. 7(12): 2794-2801. doi: https://doi.org/10.20546/ijcmas.2018.712.317 